\title{
Unusual lithospheric structure and evolutionary pattern of the cratonic segments of the South Indian shield
}

\author{
P. K. Agrawal and O. P. Pandey \\ Theoretical Geophysics Group, National Geophysical Research Institute, Uppal Road, Hyderabad 500007, India
}

(Received September 22, 2003; Revised March 3, 2004; Accepted March 3, 2004)

\begin{abstract}
The southern Indian shield, characterised by several prominent geological and geophysical features, can be divided into three distinct tectonic segments: Western Dharwar craton (WDC), Eastern Dharwar craton (EDC) and Southern Granulite terrain (SGT). With the exception of WDC, the entire crust beneath EDC and SGT has been remobilized several times since their formation during the mid- to late Archeans (3.0-2.5 Ga). In order to understand the evolutionary history of these segments, a multiparametric geological and geophysical study has been made which indicates that the south Indian shield, characterized by a reduced heat flow of $23-38 \mathrm{~mW} / \mathrm{m}^{2}$ has a much thinner $(88-163 \mathrm{~km})$ lithosphere compared to $\sim 200-450 \mathrm{~km}$ found in other global shields. In the EDC-SGT terrain, high velocity upper crust is underlain by considerably low mantle velocity with a thick high conductive/low velocity zone sandwiched at mid crustal level. Our study reveals that the entire EDC region is underlain by granulite facies rocks with a density of about 2.85 to $3.16 \mathrm{~g} / \mathrm{cm}^{3}$ at a shallow depth of about $8 \mathrm{~km}$ in the southern part and at even shallower depth of about 1 to $2 \mathrm{~km}$ below the Hyderabad granitic region in the north. Cratonic mantle lithosphere beneath EDC may contain a highly conductive, anisotropic and hydrous metasomatic zone between the depth of 90 and $105 \mathrm{~km}$ where estimated temperatures are in the range of $850-975^{\circ} \mathrm{C}$. It is likely that before the early Proterozoic, the entire south Indian shield was a coherent crustal block which subsequently got segmented due to persistent plume-induced episodic thermal reactivations during the last $2.7 \mathrm{Ga}$. These reactivations led to self destruction of cratonic roots giving rise to negative buoyancy at deeper levels which may have been responsible for crustal remobilisations, followed by regional uplifting and erosion of once substantially thick greenstone belts. Consequently, the crustal column beneath the EDC has become highly evolved and now corresponds closely to SGT at depth.
\end{abstract}

Key words: Indian shield, lithosphere, temperature, granulites, Eastern Dharwar craton, velocity structure, tectonothermal events.

\section{Introduction}

South Indian shield forms one of the most dynamic, sheared and deformed regions among the stable areas of the earth (Pandey and Agrawal, 1999). It is bounded by Godavari graben of Gondwana age in the east and partly covered by Deccan basalts of K-T boundary age in the north. This shield underwent a complex style of evolution and accretion since late Archean times. It is characterized by several geotectonic terrains evolved at different times by different processes. Thermotectonic activity can be traced almost through entire late Archean-Proterozoic era. Even during the last $130 \mathrm{Ma}$, it has been associated with high order mobility, continental rifting episodes from its western and eastern margins and a major plume interaction (Marion).

As a whole, major part of the southern Indian shield is occupied by mid-Archean-early Proterozoic crystalline rocks evolved during several episodes of magmatism and metamorphism. The remnants of the oldest Archean terrain occur as granite-gneiss-greenstones in the western part (Fig. 1). Broadly, this region can be divided into three individual blocks, exhibiting distinct tectonostratigraphic and

Copy right(c) The Society of Geomagnetism and Earth, Planetary and Space Sciences (SGEPSS); The Seismological Society of Japan; The Volcanological Society of Japan; The Geodetic Society of Japan; The Japanese Society for Planetary Sciences; TERRAPUB. geochronologic characters. These are Western Dharwar craton (WDC), Eastern Dharwar craton (EDC) and Southern Granulite terrain (SGT) (Fig. 1). Among them, the SGT situated in the southern part of the peninsula had undergone extensive regional metamorphism during late Archean and Pan African times $(550 \pm 30 \mathrm{Ma})$. In view of the above, an attempt has been made here to (i) delineate deep structure of the crust and mantle lithosphere beneath these segmented blocks and (ii) study their evolutionary and deformational pattern by integrating available geological and geophysical data.

\section{Geologic and Geotectonic Pattern}

Simplified geologic and tectonic setting of the south Indian shield is shown in Figs. 1 and 2. Among the three segments, WDC forms the oldest unit containing mid to late Archean cratonic nuclei, over which lies vast exposures of high grade schists (3.0-3.4 Ga), granite and gneisses (Radhakrishna and Naqvi, 1986; Naqvi and Rogers, 1987). The entire segment is devoid of Proterozoic tectono-thermal events with rock types showing low temperature metamorphism. In contrast, the EDC is characterised by late Archean-early Proterozoic ( $\sim 2.5 \mathrm{Ga})$ cratonic growth with low pressure metamorphism and remoblisation of crustal blocks, containing abundant calc-alkaline to K-rich gran- 


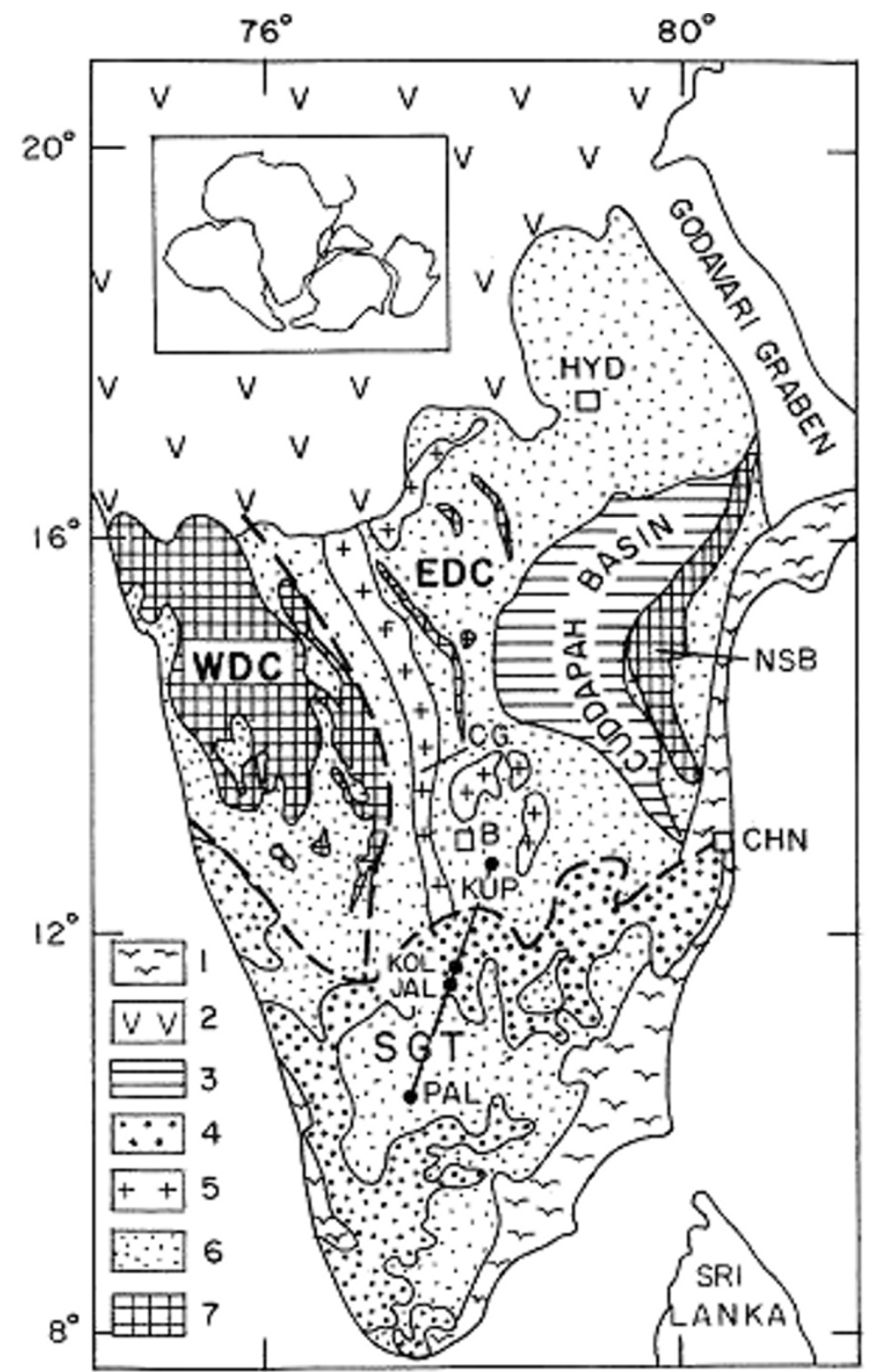

Fig. 1. Generalized geological map of south Indian shield (GSI, 1993). WDC: Western Dharwar Craton; EDC: Eastern Dharwar Craton; SGT: Southern Granulite Terrain; KUP: Kuppam; PAL: Palani; KOL: Kolattur; JAL: Jalakandapuram; HYD: Hyderabad; B: Bangalore; CHN: Chennai; CG: Closepet granite; NSB: Nellore schist belt; 1: Alluvium; 2: Deccan volcanics; 3: Mid-proterozoic sedimentary basin; 4: Charnockites; 5: Granites; 6: Granite, gneiss, migmatites; 7: Greenstone belt (Dharwar). Inset shows assembly of Gondwana continental blocks including India.

itoids along with thin elongated greenstone belt (Harish Kumar et al., 2003). This region evolved during various episodes from $2.7 \mathrm{Ga}$ to $1.1 \mathrm{Ga}$, the last one being a major kimberlitic event (Anil Kumar et al., 1993). This terrain is extensively intruded by mafic dyke swarms and is unconformably overlain by mid-Proterozoic Cuddapah super group sedimentary sequence. Most of the granites and gneisses of EDC have elevated initial ${ }^{87} \mathrm{Sr} /{ }^{86} \mathrm{Sr}$ ratios (Pandey et al., 1995). EDC is separated from WDC by a steep mylonitic zone along the Chitradurga fault zone (CDF in Fig. 2) which runs through the middle of the Dharwar craton. A thrust zone possibly exists around the eastern margin of EDC (Drury et al., 1984). It also contains a number of hot springs (Fig. 2).

South of WDC and EDC lies the SGT terrain below latitude $12.5^{\circ} \mathrm{N}$. This zone can be divided into two distinct terrains situated either side of Palghat-Cauvery Shear Zone.
(PC in Fig. 2). The northern block is made up of late Archean-early Proterozoic (?) granulites consisting mainly of charnockites and retrograde gneisses while the southern block is of Pan-Africann age $(550 \pm 30 \mathrm{Ma})$ and is composed of charnockites, khondalites, granites and gneisses. Some sections of SGT are even pressently tectonically active showing large uplift like Nilgiri (Fig. 2). Deepest part of the granulitic crust is exposed in many areas.

\section{Heat Flow Distribution, Temperature Regime and Geoelectric Signatures}

Heat flow in the Dharwar craton (Fig. 3) shows a wide range from 27 to $75 \mathrm{~mW} / \mathrm{m}^{2}$ with an average of $31 \pm 4$ and $40 \pm 11 \mathrm{~mW} / \mathrm{m}^{2}$ for WDC and EDC respectively. Heat flow variation in SGT is large with an average of $36 \pm 4 \mathrm{~mW} / \mathrm{m}^{2}$ for the northern block and $47 \pm 8 \mathrm{~mW} / \mathrm{m}^{2}$ for the southern 


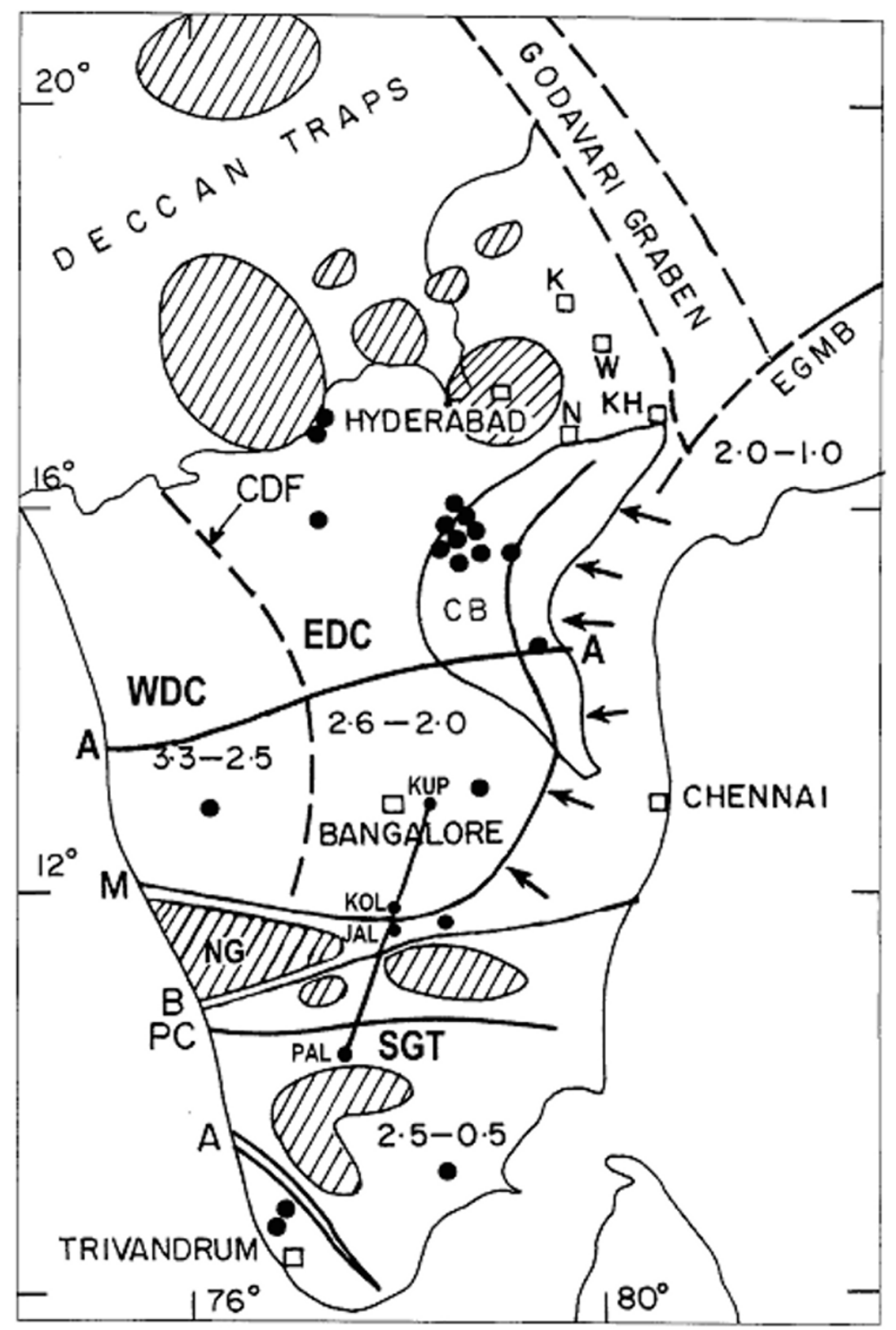

Fig. 2. Simplified geotectonic map of South Indian shield. M: Moyar shear zone; B: Bhavani shear zone; A: Achankovil shear zone; PC: Palghat-Cauvery shear zone; EGMB: Eastern Ghat mobile belt; CB: Cuddapah basin; CDF: Chitradurga Fault zone; K: Karimnagar; W: Warangal; KH: Khammam; $\mathrm{N}$ : Nalgonda; NG: Nilgiri. Ages are in Ga. Arrows indicate direction of thrusting. Solid dots indicate location of hot springs. Uplifted regions (Krishna Brahmam and Negi, 1973; Thakur and Nagarajan, 1992; Rantsman et al., 1995 etc.) are shown by slanted lines. AA indicates location of CSS profile across WDC and EDC along which velocity-depth distribution has been shown in Fig. 5. Location of seismic profiles from Kuppam (KUP)-Jalkandapuram (JAL) and Kolattur (KOL)-Palani (PAL) as shown in Fig. 6 is also given.

block.

In order to estimate deep seated temperatures, we assume an exponential decrease of heat production with depth and calculate the temperature $T$ at a depth $z$ using the following relationship (Lachenbruch, 1968):

$$
T(z)=T_{o}+\frac{q_{r}}{K} z+\frac{D^{2}}{K} A_{o}[1-\exp (-z / D)]
$$

where $T_{o}$ is surface temperature, $K$ is thermal conductivity, $A_{o}$ is heat production, $q_{r}$ reduced heat flow and $D$ is exponential decay scaling parameter (or characteristic depth). In these calculations, To is taken as $25^{\circ} \mathrm{C}$, thermal conductivity is taken uniformly as $3.0 \mathrm{~W} / \mathrm{m}^{\circ} \mathrm{C}$ (except for NSGT 2.44 and
SSGT 2.30; Ray et al., 2000) and characteristic depth $10 \mathrm{~km}$ as obtained from heat flow-heat generation relationship for the Indian shield (Pandey, 2003). Temperature-depth calculations depend heavily on the heat production value assigned to the upper crust. Thus, for WDC and EDC, we use the detailed compilation of Gupta et al. (1991) for the Dharwar craton. In case of EDC, we have not considered anomalous heat generation value of Hyderabad granitic terrain and for WDC, we restrict only to the values belonging to the Chitradurga supracrustal belt and its surrounding areas. Our recent detailed study (Pandey et al., 2002) suggests that highly radioactive granitic layer at Hyderabad does not extend beyond a kilometer or so at depth. For SGT, heat generation 


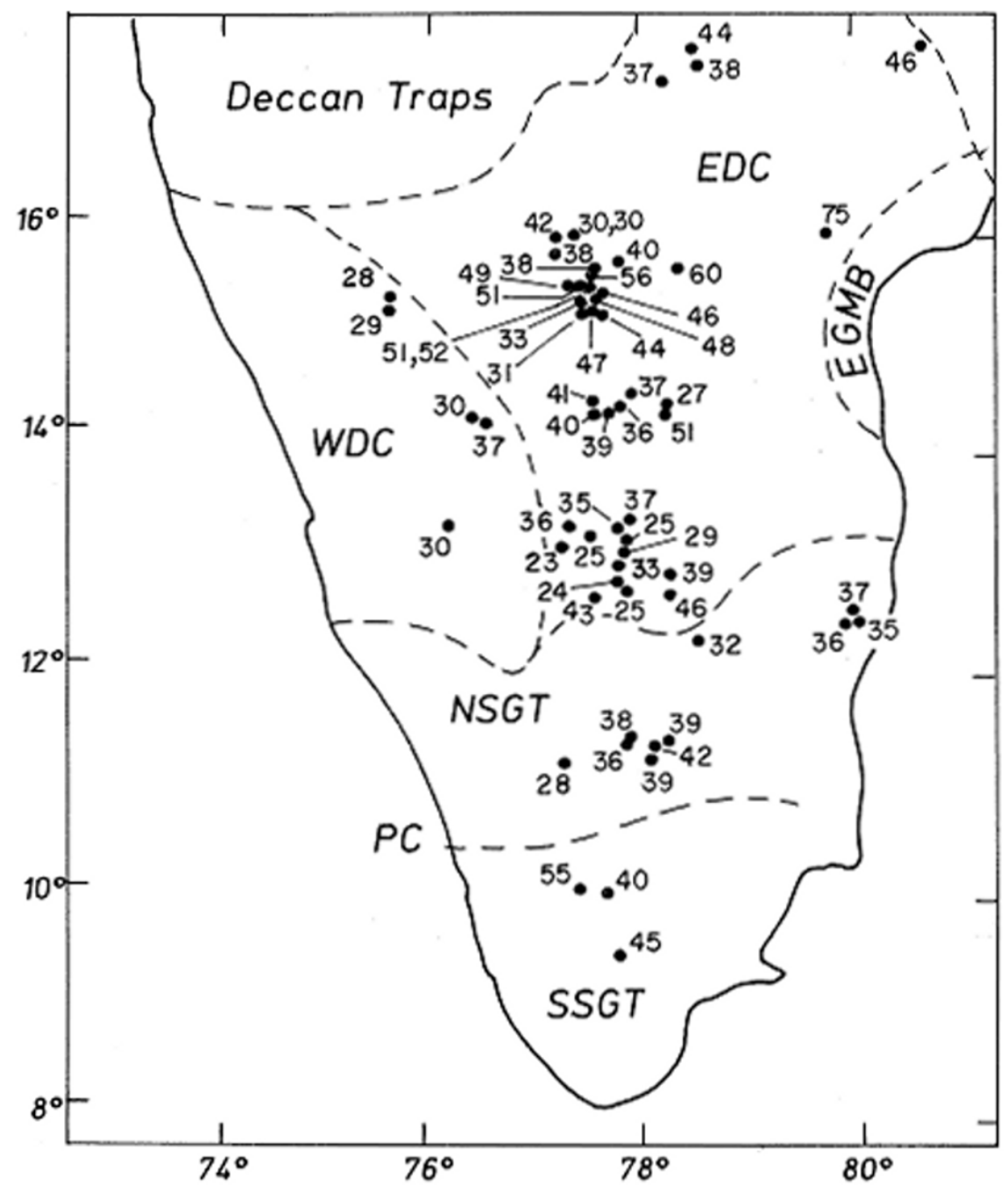

Fig. 3. Heat flow (in $\mathrm{mW} / \mathrm{m}^{2}$ ) distribution in the south Indian shield. Data is taken from Gupta and Rao (1970), Gupta et al. (1987, 1991), Roy and Rao (2000) and Rao et al. (1976, 2001). NSGT and SSGT denote Northern and Southern block of SGT. EGMB: Eastern Ghat mobile belt.

data is taken from a very detailed work of Ray et al. (2000) covering hundreds of measurements. The reduced heat flow (i.e. heat flow coming out from the lower crust and upper mantle) is then estimated by removing the effect of a $10 \mathrm{~km}$ thick crustal radioactive column from the observed mean surface value, which varies from 23 to $38 \mathrm{~mW} / \mathrm{m}^{2}$ among the segments.

Calculated temperature-depth distribution for WDC, EDC and SGT is shown in Fig. 4 from which the base of lithosphere is determined as being the mantle solidus, i.e. intersection of the geotherm with the peridotite incipient melting point curve. This provides lithospheric base at 88 to 163 $\mathrm{km}$ depth which is considerably low compared to 200-300 $\mathrm{km}$ found in other stable areas of the earth (Chapman and Pollack, 1977). It implies that lithosphere beneath these segments besides being unusually shallow, is also quite warm. Such an inference is supported by seismic evidence that suggest even shallower cratonic root depths $(\sim 100 \mathrm{~km}$ only) beneath the Indian shield compared to about $250-450 \mathrm{~km}$ found elsewhere (Polet and Anderson, 1995). The cratonic mantle lithosphere appears to contain a highly conductive, hydrous and seismically anisotropic metasomatic zone between the depth of 90 and $105 \mathrm{~km}$ (Saul et al., 2000; Sastry et al.,
1990) where the estimated temperature could be $850-975^{\circ} \mathrm{C}$. This zone is found at much deeper level of $\sim 150 \mathrm{~km}$ or more in other global stable areas. All the thermal parameters of WDC, EDC and SGT are summarised in Table 1.

\section{Crustal Velocity Structure}

Controlled source seismics (CSS) derived velocity-depth function along an E-W profile across WDC and EDC (AA in Fig. 2) is shown in Fig. 5. In WDC, crustal $P$-wave velocity increases from $6.0 \mathrm{~km} / \mathrm{s}$ at surface to $6.2 \mathrm{~km} / \mathrm{s}$ at 22-24 km depth and then $6.8 \mathrm{~km} / \mathrm{s}$ to $7.0 \mathrm{~km} / \mathrm{s}$ above Moho, identified at an average depth of $40 \mathrm{~km}$ with a high $P n$ velocity of $8.4 \mathrm{~km} / \mathrm{s}$ (Reddy et al., 2000; Sarkar et al., 2001), while in EDC, seismic velocity increases from $5.9 \mathrm{~km} / \mathrm{s}$ at surface to $6.2 \mathrm{~km} / \mathrm{s}$ at the depth of $5-8 \mathrm{~km}$ and then 6.7 to $7.0 \mathrm{~km} / \mathrm{s}$ at depth of $20-37 \mathrm{~km}$. Here, Moho depth and $P n$ velocity are $37 \mathrm{~km}$ and $7.8 \mathrm{kms}$ respectively (Reddy et al., 2000). As regards SGT, a coincident deep seismic reflection and refraction study has recently been conducted across the Dharwar craton in the north-south direction from Kuppam KUP) to Palani (PAL) (Figs. 1,2). This profile runs through the entire breadth of the northern block of SGT In this region, crust has been interpreted as consisting of four 


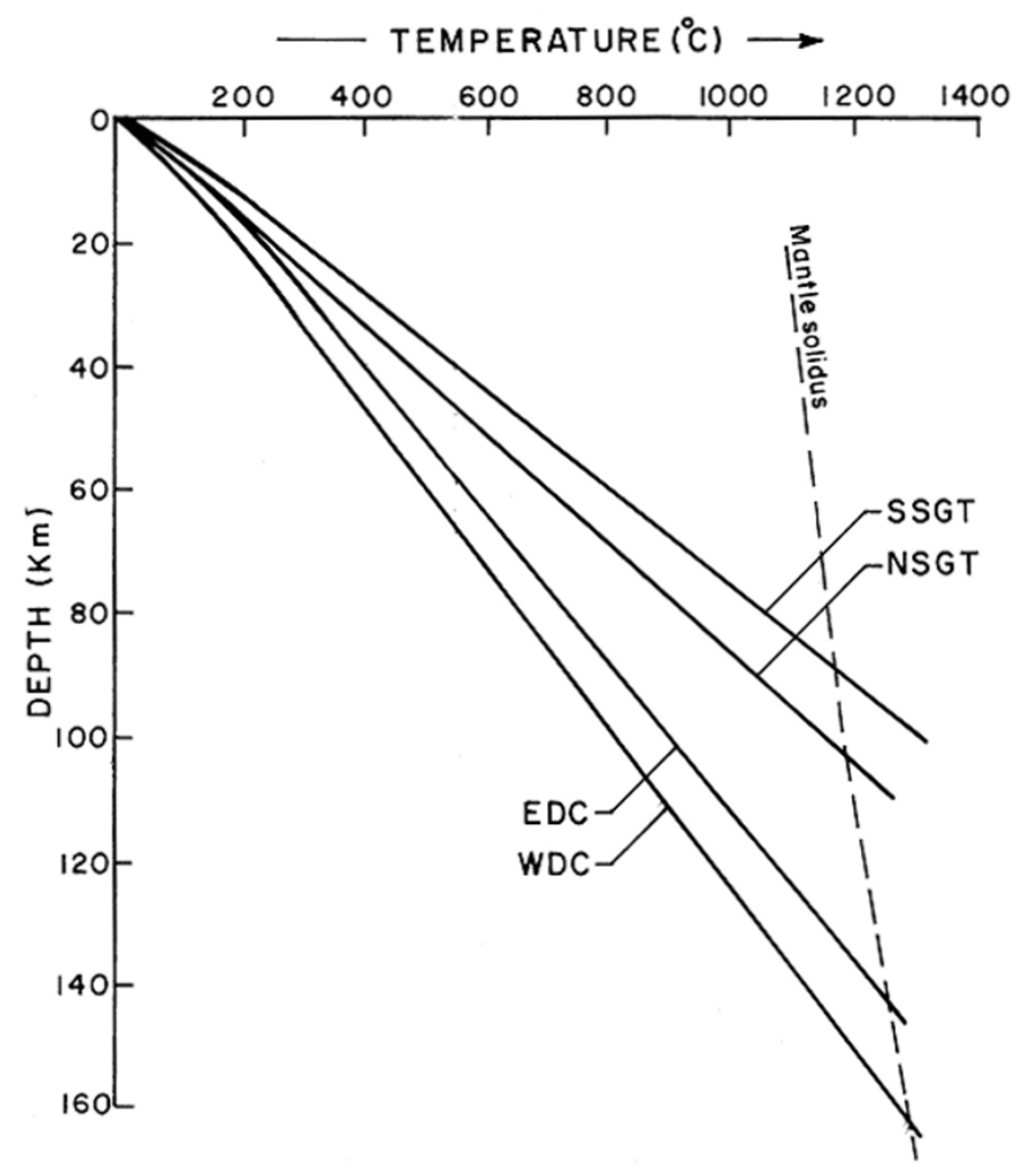

Fig. 4. Temperature-depth distribution in WDC, EDC, NSGT and SSGT.

Table 1. Geothermal parameters of the cratonic segments of south Indian shield.

\begin{tabular}{lcccc}
\hline & WDC & EDC & NSGT & SSGT \\
\hline Number of $q$ data & 5 & 43 & 10 & 3 \\
Heat flow range $\left(\mathrm{mW} / \mathrm{m}^{2}\right)$ & $28-37$ & $23-75$ & $28-42$ & $40-55$ \\
Mean heat flow $\left(\mathrm{mW} / \mathrm{m}^{2}\right)$ & $31 \pm 4$ & $40 \pm 11$ & $36 \pm 4$ & $47 \pm 8$ \\
Heat generation $\left(\mu \mathrm{W} / \mathrm{m}^{3}\right)$ & 0.81 & 1.48 & 0.21 & 0.90 \\
Reduced heat flow $\left(\mathrm{mW} / \mathrm{m}^{2}\right)$ & 23 & 25 & 34 & 38 \\
Estimated temperature & & & & \\
at $40 \mathrm{~km}\left({ }^{\circ} \mathrm{C}\right)$ & 358 & 407 & 485 & 561 \\
Estimated depth to & 163 & 142 & 103 & 88 \\
Asthenosphere $(\mathrm{km})$ & & & & \\
\hline
\end{tabular}

Data Source: Gupta et al. (1987, 1991); Roy and Rao (2000); Gupta and Rao (1970); Rao et al. (1976, 2001); Ray et al. (2000).

layers corresponding to upper, middle, low velocity layer and the lower crust (Reddy et al., 2003). $P$-wave velocities for these layers are 6.1-6.3, 6.5-6.55, 5.90-6.05 and 7.1 km/s respectively (Fig. 6). Moho is identified at a depth of around $40-45 \mathrm{~km}$.

Recent analysis of teleseismic receiver function (Gupta et al., 2003; Sarkar et al., 2003) also suggests a considerable shallowing of Moho in EDC (average $\sim 35 \mathrm{~km}$ ) compared to an average of $\sim 44 \mathrm{~km}$ in WDC and $\sim 46 \mathrm{~km}$ in SGT. If we take into account an erosion of $15-25 \mathrm{~km}$ from SGT, then almost a doubling of crust is envisaged there, consequent to a possible subduction of WDC underneath SGT during Archean times (Pandey and Manglik, 2003). In that case, the low velocity layer found beneath SGT would correspond to a sandwitched granitic crust.

\section{Subcrustal Tomographic Study}

Srinagesh and Rai (1996) carried out a three-dimensional $P$-wave velocity tomographic study using teleseismic rays from a variety of azimuths to find velocity structure of the 


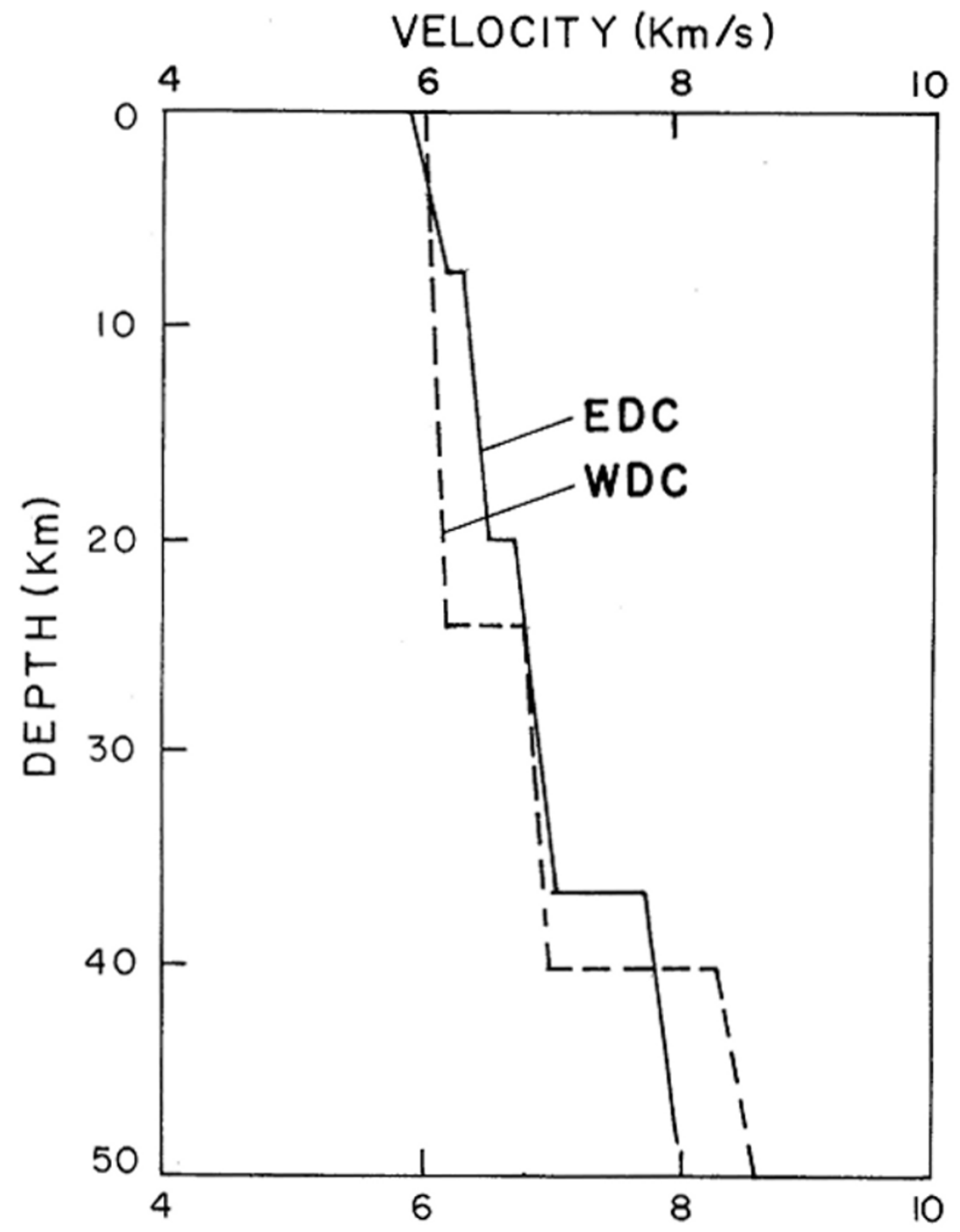

Fig. 5. Crustal $P$-wave velocity-depth distribution for WDC and EDC (after Reddy et al., 2000).

crust and uppermost mantle beneath south Indian craton. According to them, the tomographic images of various geotectonic blocks show a definite correlation with surface geology and velocity images in the upper mantle to a depth of about $177 \mathrm{~km}$. Averaged $P$-wave velocity variations beneath these regions at the depth range of 40 to $177 \mathrm{~km}$ (corresponding to the lithospheric mantle) reveals large differences in the velocity features (Fig. 7). For example, higher velocities of about 1 to $2 \%$ is observed beneath WDC compared to much lower velocities of $-0.3 \%$ to $-1.6 \%$ beneath SGT and $-0.4 \%$ to $-1.8 \%$ beneath EDC. It may be of interest to note that between WDC and SGT there is a velocity contrast of almost $2 \%$ to $3 \%$ at the lithospheric mantle level. Higher upper mantle velocity beneath WDC can be attributed to relatively cold nature of the lithosphere relative to EDC and SGT.

\section{Gravity Anomaly Pattern}

Gravity field has been gainfully utilized to understand the subsurface mass/density distributions and also the extension of concealed geologic features. Depending upon the wavelength the Bouguer gravity anomaly may be caused due to sources lying in the crust or beyond. The contours of a care- fully prepared gravity map can be a useful guide in understanding the trend of the extension of a geological formation. The regional gravity map of a part of the south Indian shield (Fig. 8) (NGRI, 1975) depicts contour patterns over WDC, EDC and SGT. An examination of the anomaly map shows that the trend of the gravity contours in the EDC and WDC is NW-SE while over SGT it is dominantly NE-SW. Observed gravity patterns in SGT appear to continue into EDC as shown by the solid dotted line. It may be pertinent to mention here that a high order negative gravity bias (around -120 mgal) noticed over WDC compared to EDC and SGT, may be attributed to the fact that WDC has remained altogether unaffected by the past tectonothermal events indicating relatively cold and thicker lithosphere associated with higher uppermost mantle velocity (Fig. 7).

\section{Upliftment and Erosion of Greenstone Belt in EDC}

Except cratonic areas of WDC, almost the entire southern shield has been episodically uplifting which seems to be continuing even today. (Radhakrishna, 1993) (Fig. 2). Its surrounding region, like the Western Ghats bordering Deccan 

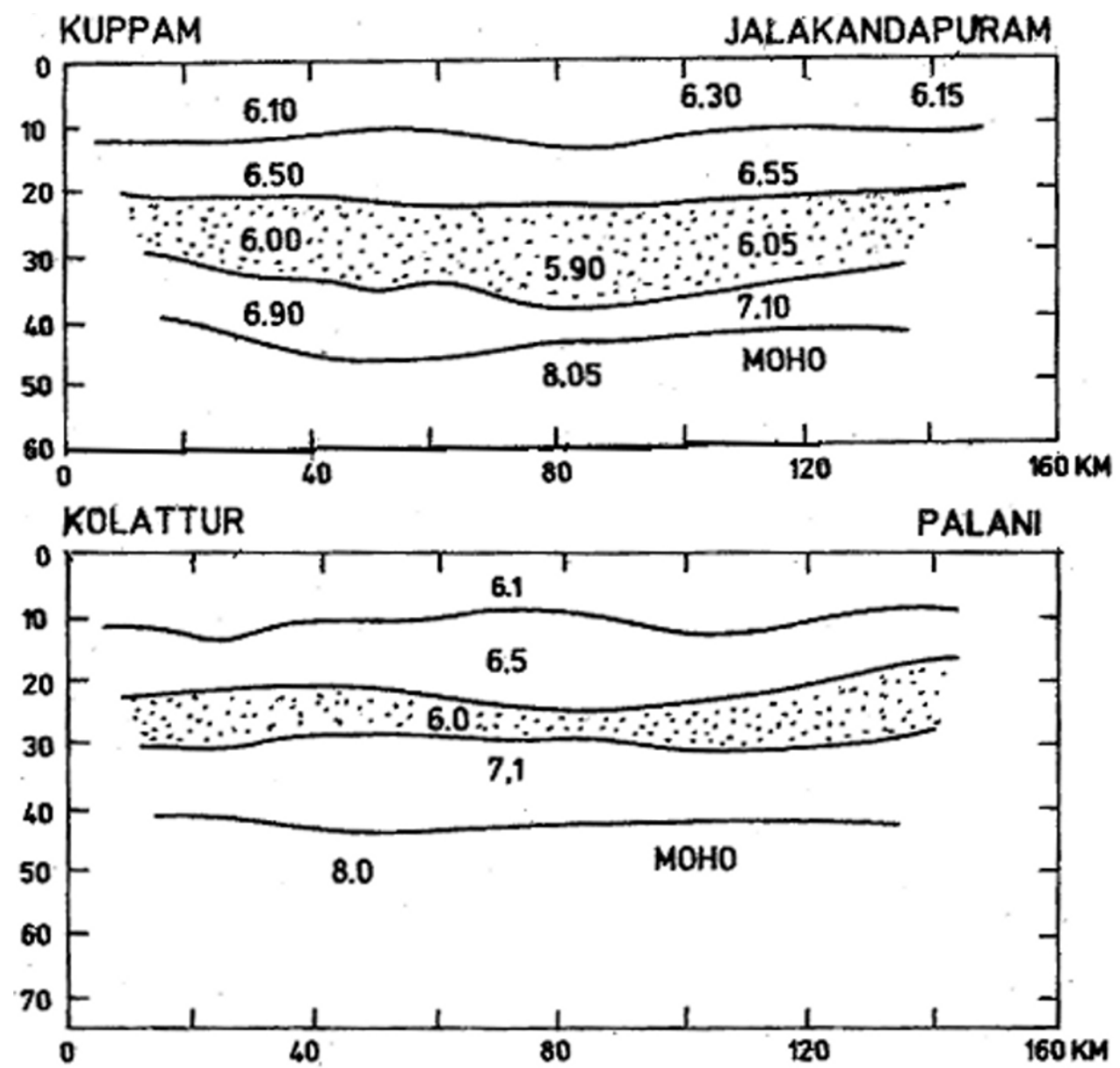

Fig. 6. 2-D velocity structure along Kuppam—Jalakandapuram and Kolattur-Palani traverses the location of which is shown in Figs. 1, 2 (Reddy et al., 2003). Dots refer to low velocity zone.

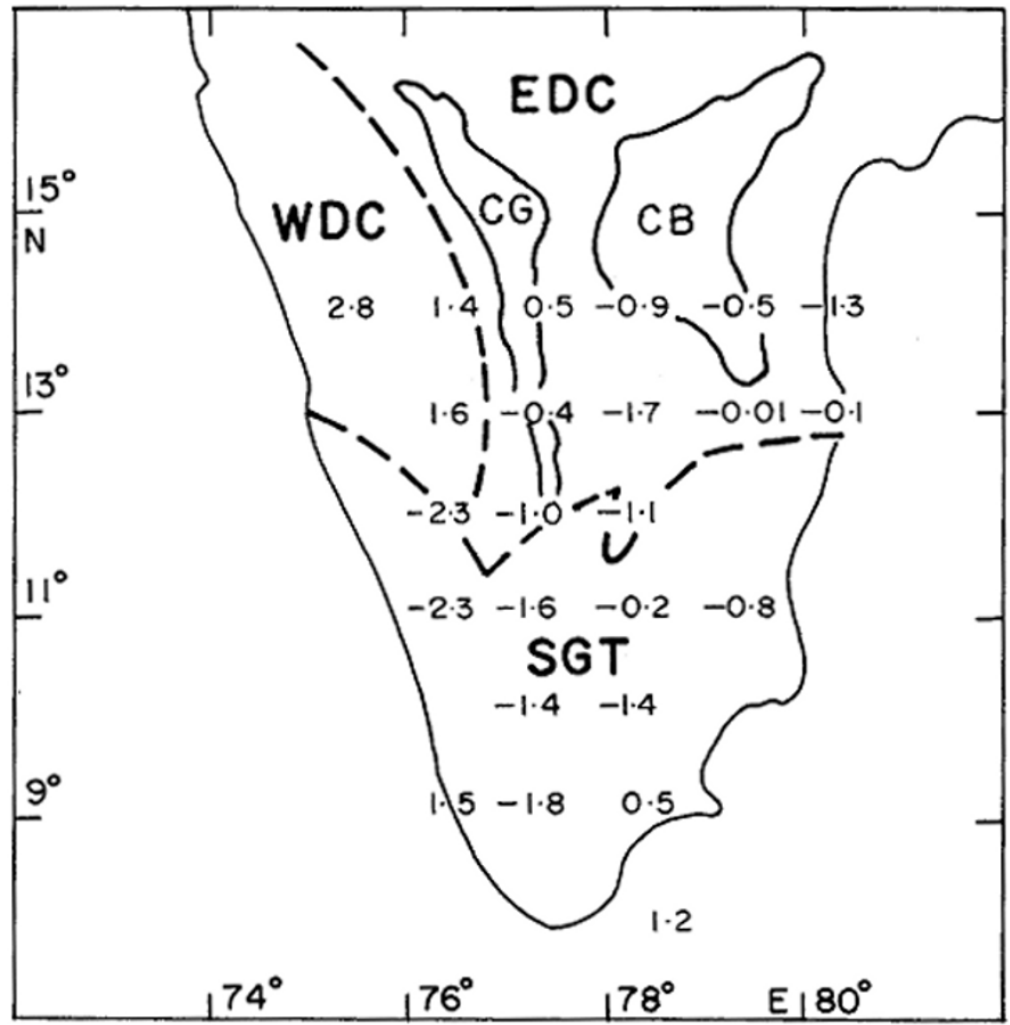

Fig. 7. Averaged $P$-wave velocity variations (\%) at the depth level of $40-177 \mathrm{~km}$ in the Southern Indian shield (after Srinagesh and Rai, 1996 ). CG: Closepet granite; CB: Cuddapah basin. 


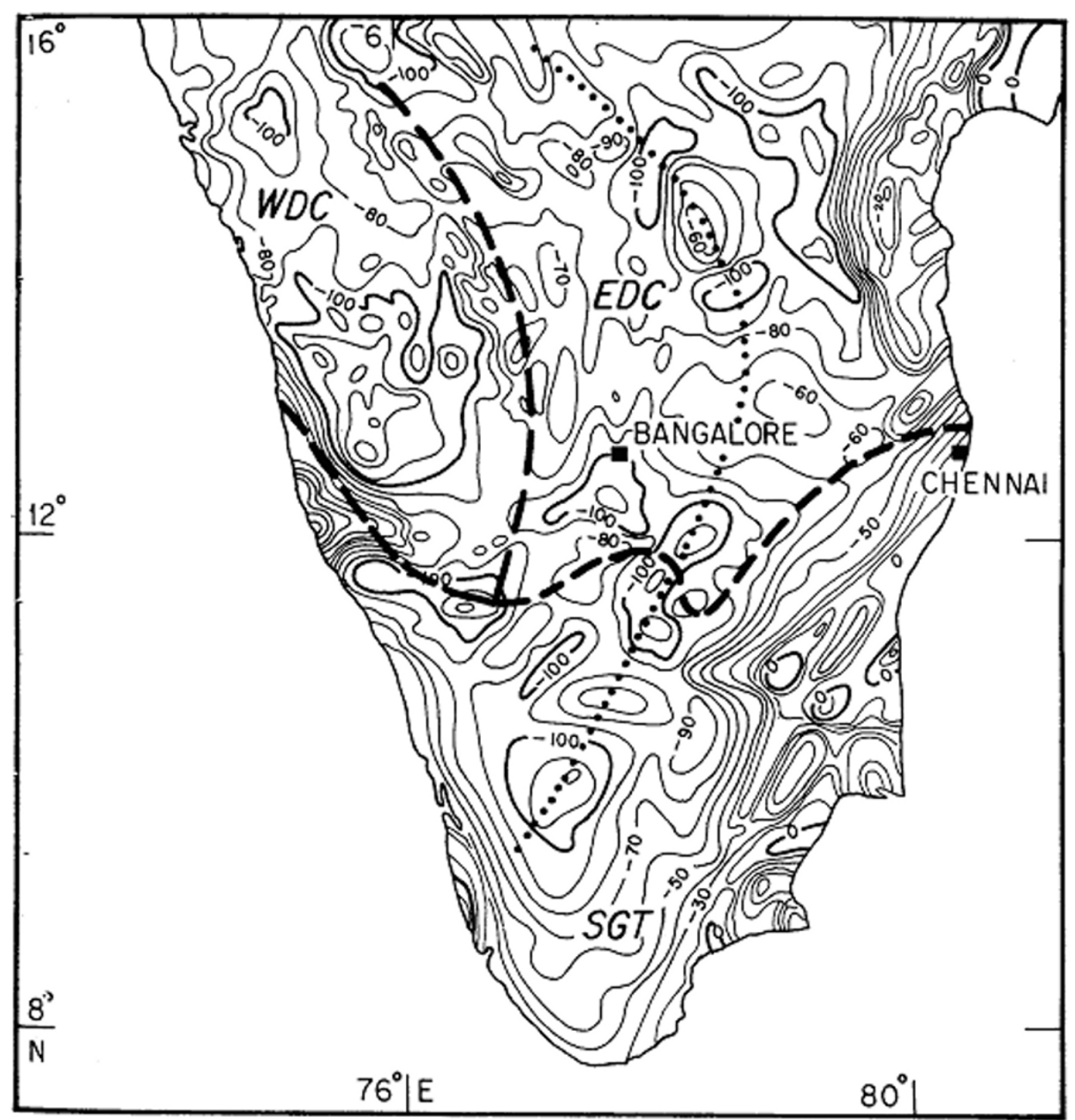

Fig. 8. Bouguer gravity anomaly map of India (Scale 1:5000,000) (NGRI, 1975). Possible extension of gravity trends from SGT to EDC is shown by solid dotted line.

Traps on the west coast and the Eastern Ghat physiographic province (EGMB) (Fig. 2) has also been uplifting (Ramkrishnan et al., 1994; Babu, 1998). Due to uplift and denudation, once quite thick ( $5 \mathrm{~km}$ or even more) exposed greenstone belts which earlier covered the entire southern shield till the close of the Dharwar age, appears to have been removed away from the surface (Babu, 1998). As a result, we now only see the underlying granite-gneiss rocks exposed at the surface. Only a few narrow strips of the greenstone schist belt now remains between Closepet granite (CG) and Nellore schist belt (NSB). The latter is still about $22 \mathrm{~km}$ wide and 0.8 to $1.5 \mathrm{~km}$ thick and shows marked resemblance with the Holenarsipur schist belt $(>3.0 \mathrm{Ga})$ of WDC.

\section{Discussion of Results and Conclusions}

Presently the south Indian shield appears to form a mosaic of several blocks, evolved at various times by different geotectonic processes. Numerous tectonothermal events, encompassing almost entire Proterozoic period appears to have affected the greater part of this region, particularly EDC and
SGT. For example, a close look at Figs. 5 and 6 would reveal that $P$ wave velocity in upper crust is much lower (6.0 to 6.2 $\mathrm{km} / \mathrm{s}$ ) in WDC than EDC and SGT. Similarly $P n$ wave velocity of $8.4 \mathrm{~km} / \mathrm{s}$ below WDC is much higher than $7.8 \mathrm{~km} / \mathrm{s}$ recorded below EDC. Similar is the case for the mantle lithosphere (40-177 km) where seismic tomographic modelling indicates the presence of $1 \%$ to $2 \%$ higher velocities beneath WDC, compared to much lower velocities beneath EDC and SGT (Fig. 7). The lithospheric thermal picture reveals similar pattern (Table 1). Lithosphere is colder and much thicker beneath WDC compared to other tectonic segments. Apart from this, there is a presence of mid-crustal high conductivity layer in EDC (Gokarn et al., 1998; Sastry et al., 1990) and low velocity layer $(\sim 6.0 \mathrm{~km} / \mathrm{s})$ in SGT. No such high conductivity/low velocity layer is reported from WDC.

Moreover, there are several regions in EDC and SGT which are neotectonically uplifting (Fig. 2) and have remained active since late Archean with large scale episodic crustal remobilisation, kimberlitic, granitic and basic dyke intrusions. Kimberlitic intrusions occuring in the proxim- 


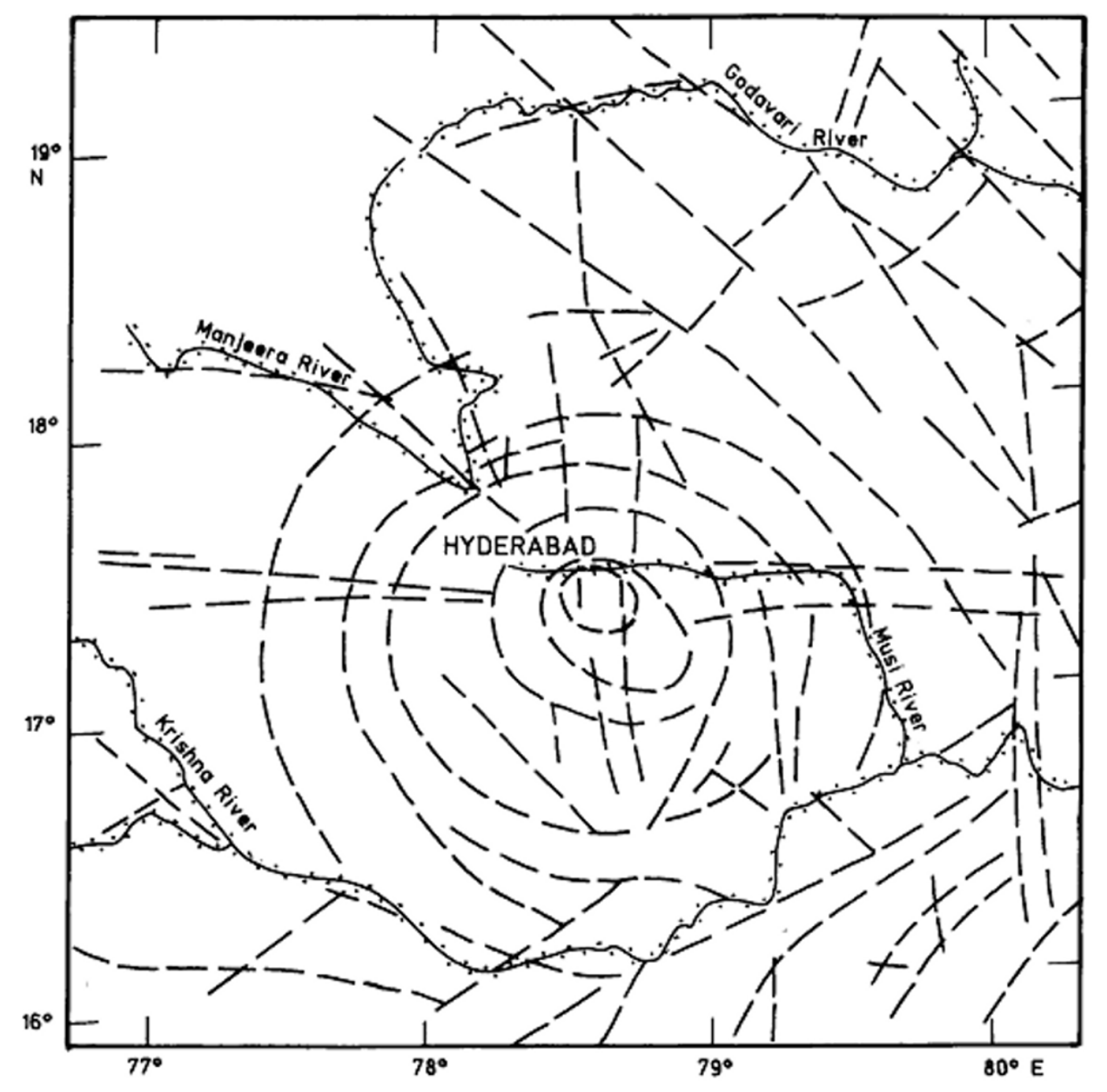

Fig. 9. Morpho-structural pattern around Hyderabad segment of EDC (revised after Rantsman et al., 1995).

ity of the intersection of major structural lineaments in EDC (Chetty, 2000) are absent in WDC. Geophysically too, the lithosphere beneath EDC and SGT differs from that of WDC, although they may appear to be similar to each other. $P$ wave velocity of $6.3-6.5 \mathrm{~km} / \mathrm{s}$ obtained between the depth of 8 and $20 \mathrm{~km}$ beneath EDC compares favourably with that of $6.5 \mathrm{~km} / \mathrm{s}$ between 10 and $20 \mathrm{~km}$ depth in SGT (Figs. 5, 6). Similarly lower crustal velocity between $30 \mathrm{~km}$ and Moho is almost identical ( 6.9 to $7.1 \mathrm{~km} / \mathrm{s}$ ) for both the segments.

Since upper crustal granulites in SGT are associated with velocities of $6.1-6.3 \mathrm{~km} / \mathrm{s}$ (Fig. 6), the velocities of $6.3-6.5$ $\mathrm{km} / \mathrm{s}$ obtained below $8 \mathrm{~km}$ in EDC would definitely correspond to granulite facies rocks. This inference would be strengthened further, if we convert this velocity into density following Barton (1986), Sarma (1994) and Birch's equation (Anderson, 1972). The conversion results in a range from $2.85-3.16 \mathrm{~g} / \mathrm{cm}^{3}$. These order of densities would correspond to Amphibolites in low grade terrain to granulitic facies gneisses, migmatites, Khondalites and Basicultrabasic charnockites in high grade terrain (Subrahmanyam and Verma, 1981). Therefore, we infer that below a depth of $\sim 8 \mathrm{~km}$ onwards, EDC crust corresponds more closely to SGT which are well supported by geophysical observations (Figs. 3-8). Interestingly enough, average $S$-velocity and Poisson's ratio are also almost similar $(3.7-3.8 \mathrm{~km} / \mathrm{s}$ and 0.24-0.27 respectively) beneath EDC and SGT (Saul et al., 2000; Ravi Kumar et al., 2001; Gupta et al., 2003).

Geologically, in addition, there are several studies to support the occurrence of granulite facies rocks in several parts of EDC. For example, charnockite assemblage minerals and in particular pyroxene bearing granodiorites and granites are known to occur in the Hyderabad granitic region situated in the northern part of EDC (Sarma, 1954; Sitaramayya, 1971). They evolved at considerable depth from an anatectic melt formed at high temperature $\left(\sim 800^{\circ} \mathrm{C}\right)$ and under 5 to $10 \mathrm{~kb}$ water vapour pressure (Sitaramayya, 1971). Our recent geological and geophysical studies of the uplifting Hyderabad granitic region (Pandey et al., 2002) suggests the presence of acid to intermediate grade granulite facies rocks at a shallow depth of about one kilometer or so only, as at least 8-10 km thick high radioactive surface granitic layer has been eroded from this region due to regional upliftment which has controlled the morphotectonics and also severely disrupted the river courses and drainage pattern (Fig. 9). Charnockitisation has also been reported in the banded gneissic granites and alaskites at Nalgonda town of EDC situated about $90 \mathrm{~km}$ SE of Hyderabad (Fig. 2) and its surroundings (Somayajulu and Veeraiah, 1981). Besides this, a large zone of exposed 


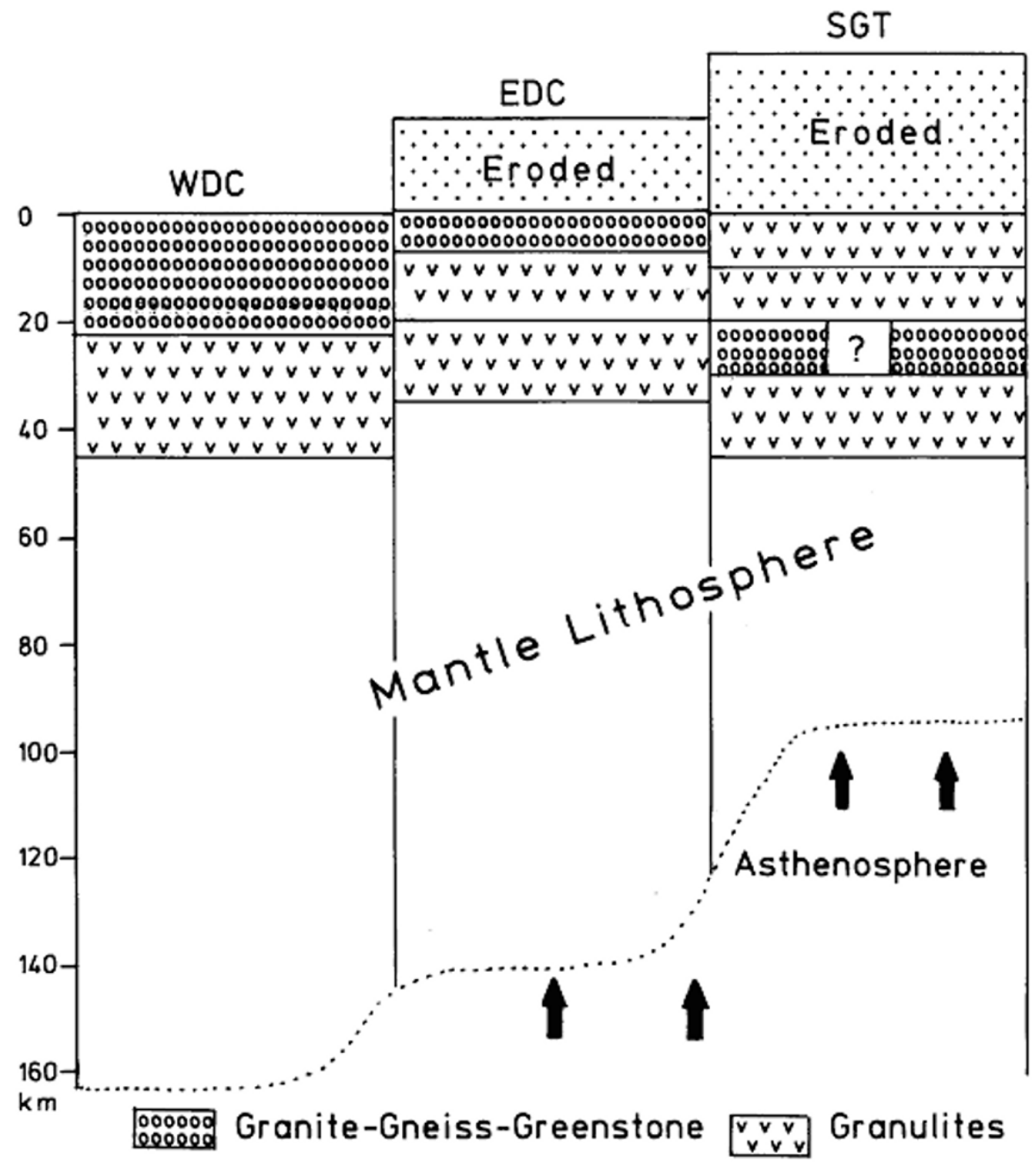

Fig. 10. A possible crustal cross section beneath WDC, EDC and SGT, as inferred from available geological and geophysical informations.

granulite terrain has been discovered paralleling the southern flank of Godavari graben (Rajesham et al., 1993) covering the districts of Kraimnagar, Warangal and Khammam (Fig. 2).

Presence of granulitic facies rocks at a shallow depth beneath EDC is hardly surprising, considering its past geologic history when it experienced extensive tectonothermal magmatic activities at around $2.7-2.2 \mathrm{Ga}, 1.9-1.8 \mathrm{Ga}, 1.2-1.1$ Ga, and 0.85-0.5 Ga (Naqvi and Rogers, 1987; Rogers and Callahan, 1987; Acharya, 1997; Anil Kumar et al., 1993; Radhakrishna and Naqvi, 1986 etc.). The earliest activity (2.7-2.5 Ga) was caused by a rising mantle plume beneath a matured ancient crust which induced low degree melting of upper mantle resulting in generation and accretion of large quantity of calc-alkaline magmas observed in EDC (Jayananda et al., 2000; Harish Kumar et al., 2003). In fact, all other Proterozoic thermal events might have some associations with the rising mantle plume in some way or the other. For example, the presence of large number of ex- posed Proterozoic kimberlites $(\sim 1.1 \mathrm{Ga})$ and lamproites are nothing but plume generated. The plume origin conforms well with the models of the crystallisation of diamonds in the subcontinental lithosphere (Haggerty, 2000). Besides, this region has also been affected by a major plume activity as late as 110-88 Ma (Curray and Munasinghe, 1991; Storey, 1995) which is well reflected in various geophysical fields (Reddy et al., 1993). The heat and fluids associated with these plume-generated magmatic activities seem to have caused crustal reworking, differentiation, dehydration and high temperature-low pressure metamorphism, besides large scale regional uplifting and consequent erosion. This is the reason why a thick column of greenstone sequences from EDC has disappeared leaving behind only a few of its remnants and exposures at the surface. In fact, almost 15-20 $\mathrm{km}$ of the upper crust or even more is reported to have been eroded away from the Archean low- to high-grade transition zone lying around $12-13^{\circ} \mathrm{N}$ (Condie et al., 1982) In some parts of the SGT, even the deepest part of the granulitic crust 
is now exposed.

We believe that the southern Indian shield, comprising now of WDC, EDC and SGT segments were a coherent crustal block till about late Archean which became geologically and geophysically different during course of time lending credence to the observations of Rogers (1986). These blocks became unrelated as they evolved, differentiated and metamorphosed consequent to episodic lithosphere-plume interaction. Lithospheric mantle beneath these regions were not strong enough to resist the forces of these events which ultimately resulted in destroying the deeper roots, thereby causing negative buoyancy. Moho beneath EDC is now at least 8-10 km less than WDC and SGT and its characters are more close to SGT than WDC. A plausible crustal cross section, based on currently available geoscientific data over WDC, EDC and SGT is shown in Fig. 10.

Acknowledgments. We are extremely thankful to Drs. U. Raval, S. M. Naqvi, K. Sain, V. Divakara Rao, T. R. K. Chetty for helpful discussions and to Messrs. S. Jamaluddin, A. Shyam Vaidya and P. Sunder Rao for drafting the figures. Mr. V. Subrahmanyam has helped in the preparation of the manuscript. The permission accorded by the Director, National Geophysical Research Institute, Hyderabad to publish this work is gratefully acknowledged.

\section{References}

Acharya, S. K., Evolutionary characters of the Gondwanic Indian crust, Indian Minerals, 51, 1-24, 1997.

Anderson, O. L., Patterns in elastic constants of minerals important to Geophysics, In The Nature of the Solid Earth, edited by E. C. Robertson, pp. 575-613, McGraw-Hill, U.S.A., 1972.

Anil Kumar, V. M. Padma Kumari, A. M. Dayal, D. S. N. Murthy, and K. Gopalan, $\mathrm{Rb}-\mathrm{Sr}$ ages of Proterozoic kimberlites of India, evidence for contemporaneous emplacement, Precamb. Res., 62, 227-237, 1993.

Babu, V. R. R. M., Nellore schist belt, An Archean greenstone belt (A.P.), India, Geological History, A monograph (unpublished), 1998.

Barton, P. J., The relationship between seismic velocity and density in the continental crust - a useful constraint?, Geophys. J. R. astr. Soc., 87, 195208, 1986.

Chapman, D. S. and H. N. Pollack, Regional geotherms and lithospheric thickness, Geology, 5, 265-268, 1977.

Chetty, T. R. K., Superplume and the Indian diamond corridor, Workshop on Plume Tectonics, 13-14 June, NGRI, Hyderabad, India. Abstract Vol., pp. 6-8, 2000

Condie, K. C., P. Allen, and B. L. Narayana, Geochemistry of the Archean low- to high-grade transition zone, Southern India, Contr. Min. Petr., 81, 157-167, 1982

Curray, J. R. and T. Munasinghe, Origin of the Rajmahal traps and the $85^{\circ} \mathrm{E}$ ridge: preliminary reconstructions of the trace of the Croject hotspot, Geology, 19, 1237-1240, 1991.

Drury, S. A., N. B. W. Harris, R. W. Holt, G. J. Reeves-Smith, and R. J. Wightman, Precmabrian tectonics and crustal evolution in south India, $J$. Geol., 92, 3-20, 1984.

Gokarn, S. G., C. K. Rao, and G. Gupta, Magnetotelluric studies over the Dharwar craton, 35th Ann. Conv. Meeting of IGU on Continental Margins of India-Evolution, Processes and Potentials, 18-20 Nov., Goa, India, Abstract Vol., pp. 51-52, 1998.

GSI, Geological map of India, published by Geological Survey of India, 1993.

Gupta, M. L. and G. V. Rao, Heat flow studies under Upper Mantle Project, Bull. NGRI, 8, 87-112, 1970.

Gupta, M. L., S. R. Sharma, A. Sundar, and S. B. Singh, Geothermal studies in the Hyderabad granitic region and the crustal thermal structure of the southern Indian shield, Tectonophysics, 140, 257-264, 1987.

Gupta, M. L., A. Sundar, and S. R. Sharma, Heat flow and heat generation in the Archean Dharwar cratons and implications for the southern Indian shield geotherm and lithospheric thickness, Tectonophysics, 194, 107122, 1991.

Gupta, S., S. S. Rai, K. S. Prakasam, and D. Sri Nagesh, The nature of the crust in southern India: implications for Precambrian crustal evolution,
Geophys. Res. Lett., 30, 1419, 2003.

Haggerty, S. E., Diamond geology: A global view with glimpses of the Indian scene, Proc. Status, complexities and challenges of diamond exploration in India, 16-18 Oct., Raipur (India), 2000.

Harish Kumar, S. B., M. Jayananda, T. Kano, N. Shadakshara Swamy, and B. Mahabaleswar, Late Archean juvenile magnetic accretion process in the eastern Dharwar craton: Kuppam-Karimangalam area, Mem. Geol. Soc. Ind., 50, 375-408, 2003.

Jayananda, M., J.-F. Moyen, H. Martin, J.-J. Peucat, B. Auvrav, and B. Mahabaleswar, Late Archean (2550-2520 Ma) juvenile magmatism in the eastern Dharwar craton, Southern India: Constraints from geochronology, $\mathrm{Nd}-\mathrm{Sr}$ isotopes and whole rock geochemistry, Precam. Res., 99, 225-254, 2000.

Krishna Brahmam, N. and J. G. Negi, Rift valleys beneath Deccan Traps (India), Geophys. Res. Bull., 11, 207-237, 1973.

Lachenbruch, A. H., Preliminary geothermal model of the Sierra Nevada, $J$. Geophys. Res., 73, 6977-6989, 1968.

Naqvi, S. M. and J. J. W. Rogers, The Precambrian Geology of India, Oxford University Press, New York, 223 pp., 1987.

NGRI, Bouguer gravity anomaly map of India, published by National Geophysical Research Institute, Hyderabad, India, 1975.

Pandey, B. K., T. Chabria, and J. N. Gupta, Geochronological characterization of the Proterozoic terrains of peninsular India: Relevance to the first order target selection for Uranium exploration, Exploration and Research for Atomic Minerals, 8, 187-213, 1995.

Pandey, O. P., Heat flow, lithospheric thickness and tectonothermal evolution of Indian subcontinent, IUGG Abstract Volume, A, pp. 175, 2003.

Pandey, O. P. and P. K. Agrawal, Lithospheric mantle deformation beneath the Indian cratons, J. Geol., 107, 683-692, 1999.

Pandey, O. P. and A. Manglik, Thermo-mechanical structure of the south Indian shield, IUGG Abstract Volume, B, pp. 483, 2003.

Pandey, O. P., P. K. Agrawal, and T. R. K. Chetty, Unusual lithospheric structure beneath the Hyderabad granitic region, Eastern Dharwar craton, South India, Phys. Earth Planet. Int., 130, 59-69, 2002.

Polet, J. and D. L. Anderson, Depth extent of cratons as inferred from tomographic studies, Geology, 23, 205-208, 1995.

Radhakrishna, B. P., Neogene uplift and geomorphic rejuvenation of Indian peninsula, Curr. Sci., 64, 787-793, 1993.

Radhakrishna, B. P. and S. M. Naqvi, Precambrian continental crust of India and its evolution, J. Geol., 94, 145-166, 1986.

Rajesham, T., Y. J. Bhaskara Rao, and K. S. Murty, The Karimnagar granulite terrain-A new sapphirine bearing granulite provinces, South India, J. Geol. Soc. Ind., 41, 51-59, 1993.

Ramakrishnan, M., J. K. Nanda, and P. F. Augustine, Geological evolution of the Eastern Ghats mobile belt, in Workshop on Eastern Ghats Mobile Belt, Visakhapatnam, Abstracts, pp. 1-3, 1994.

Rantsman, E. Ya., T. R. K. Chetty, M. N. Rao, M. P. Alasko, M. P. Zhidkov, and A. I. Gorshikov, Explanatory brochure map of morphostructural zoning of the Himalayan belt Himalayan fore deep and the Indian shield. published by DST, India (New Delhi) and Russian Academy of Sciences, Moscow, Russia, pp. 29, 1995.

Rao, R. U. M., G. V. Rao, and H. Narain, Radioactive heat generation and heat flow in the Indian shield, Earth Planet. Sci. Lett., 30, 57-64, 1976.

Rao, R. U. M., R. Srinivasan, S. Roy, G. Koti Reddy, G. V. Rao, L. Ray, and P. Senthil Kumar, Geothermal regime and radioelemental distribution in the southern granulite province, South India, Newsletter, Deep Continental Studies in India (DST), 11, 7-10, 2001.

Ravi Kumar, M., J. Saul, D. Sarkar, R. Kind, and A. K. Shukla, Crustal structure of the Indian Shield: New constraints from teleseismic receiver functions, Geophys. Res. Lett., 28, 1339-1342, 2001.

Ray, L., P. Senthil Kumar, G. K. Reddy, S. Roy, G. V. Rao, R. Srinivasan, and R. U. M. Rao, Geothermal regime of the southern granulite province, Peninsular India, The Indian Mineralogist, 34, 19, 2000.

Reddy, P. R., V. K. Rao and P. Prasada Rao, Some geodynamics signature and their tectonic implications-Indian scenario, Proc. 29th Ann. Conv. Sem. On Perspectives and Prospects in Geosciences towards the new industrial policy, Indian Geophysical Union, Hyderabad, pp. 45-51, 1993.

Reddy, P. R., K. Chandrakala, and A. R. Sridhar, Crustal velocity structure of the Dharwar craton, India, J. Geol. Soc. Ind., 55, 381-386, 2000.

Reddy, P. R., B. Rajendra Prasad, V. Vijaya Rao, K. Sain, P. Prasada Rao, P. Khare, and M. S. Reddy, Deep seismic reflection and refraction/wideangle reflection studies along Kuppam-Palani transect in the southern granulite terrain of India, Mem. Geol. Soc. Ind., 50, 79-106, 2003.

Rogers, J. J. W., The Dharwar craton and the assembly of Peninsular India, J. Geol., 94, 129-143, 1986. 
Rogers, J. J. W. and E. J. Callahan, Radioactivity, heat flow and rifting of the Indian continental crust, J. Geology, 95, 829-836, 1987.

Roy, S. and R. U. M. Rao, Heat flow in the Indian shield, J. Geophys. Res., 105, 25587-25604, 2000.

Sarkar, D., K. Chandrakala, P. Padmavathi Devi, A. R. Sridhar, K. Sain, and P. R. Reddy, Crustal velocity structure of western Dharwar craton, South India, J. Geodynamics, 31, 227-241, 2001.

Sarkar, D., M. Ravi Kumar, J. Saul, R. Kind, P. S. Raju, R. K. Chadha, and A. K. Shukla, A receiver function perspective of the Dharwar craton (India) crustal structure, Geophys. J. Int., 154, 205-211, 2003.

Sarma, L. P., Physical properties of Indian rocks at elevated pressure and temperatures. Ph.D. Thesis (unpublished), Meerut University, Meerut, 266 pp., 1994.

Sarma, S. K., Charnockite assemblage of minerals found near the Osmania University, Hyderabad, Science and Culture, 20, 85-87, 1954.

Sastry, T. S., S. N. Prasad, B. J. Srivastava, and M. Someswara Rao, Vertical electric profile at Choutupal (Hyderabad) in peninsular India, Phys. Earth Planet. Int., 59, 229-232, 1990.

Saul, J., M. Ravi Kumar, and D. Sarkar, Lithospheric and upper mantle structure of the Indian shield from teleseismic receiver functions, Geophys. Res. Lett., 27, 2357-2360, 2000.
Sitaramayya, S., The pyroxene-bearing granodiorites and granites of Hyderabad area (The Osmania granite), The Quat. J. Geol. Min. Metal. Soc. Ind., 43, 117-129, 1971.

Somayajulu, P. V. and P. Veeraiah, Charnockitization of basic enclaves in Alaskites and granites of Nalgonda, Andhra Pradesh, Geoviews, IX, 365378, 1981.

Srinagesh, D. and S. S. Rai, Teleseismic tomographic evidence for contrasting crust and upper mantle in South Indian Archean terrains, Phys. Earth Planet. Int., 97, 27-41, 1996.

Storey, B. C., The role of mantle plumes in continental breakup: case histories from Gondwanaland, Nature, 377, 301-308, 1995.

Subrahmanyam, C. and R. K. Verma, Densities and magnetic susceptibilities of Precambrian rocks of different metamorphic grade (Southern Indian Shield), J. Geophys., 49, 101-107, 1981.

Thakur, N. K. and N. Nagarajan, Geotectonic remobilisation of the lower crustal segment of southern peninsular India, Phys. Earth Planet. Int., 73, 153-162, 1992.

P. K. Agrawal (e-mail: pramod_matin@yahoo.co.in) and O. P. Pandey 